\title{
Correction to: Proportional bargaining solutions, strictly comprehensive sets and the axiom of continuity
}

\section{Luís Carvaho ${ }^{1}$}

๑) Springer Science+Business Media, LLC, part of Springer Nature 2020

\section{Correction to: Annals of Operations Research https://doi.org/10.1007/s10479-020-03595-8}

In the original publication, the author name has a typo.

Lus Carvalho needs to be read as Luís Carvaho as per original submission.

Original article has thus been updated.

Publisher's Note Springer Nature remains neutral with regard to jurisdictional claims in published maps and institutional affiliations.

The original article can be found online at https://doi.org/10.1007/s10479-020-03595-8.

Luís Carvaho

luis.carvalho@iscte-iul.pt

1 Business Research Unit (BRU-IUL), Instituto Universitrio de Lisboa (ISCTE-IUL), cacifo 294, Av. das Forças Armadas, 1649-026 Lisbon, Portugal 